\title{
SQUATTING, THE 15-M MOVEMENT, AND STRUGGLES FOR HOUSING IN THE CONTEXT OF THE SPANISH SOCIAL CRISIS.
}

Ibán Díaz-Parra

\author{
Department of Social Geography, \\ Institute of Geography, \\ National Autonomous University of Mexico, \\ México D. F., México; \\ idiaz@igg.unam.mx
}

\section{José Candón Mena}

\begin{abstract}
Department of Audiovisual Communication and Advertising, University of Seville, Seville, Spain; jcandon@us.es
\end{abstract}

\section{Abstract}

The last few decades have seen the rise to predominance of social movements emphasizing ideological aspects of mobilisation. This new tendency invites a re-evaluation of the material aspects of social mobilisation. Since the onset of the last economic crisis, the housing issue, and mobilizations around it, have assumed increasing significance. Occupations of vacant housing in Spain by people in need have escalated rapidly. This research describes the housing movement in Spain, and occupation as a solution. Before the economic crisis, occupation was fundamentally linked with the squatting movement. Now it is linked more with struggles against eviction. This article examines the specific cases of Seville, and the Corralas movement.
Keywords: New Social Movements, Urban Problem, Housing, Crisis, 15-m, Squatting Movement.

Ocupaciones, el Movimiento 15-M y las Luchas por la Vivienda en el Contexto de la Crisis Social Española

\section{Resumen}

En las últimas décadas hemos visto un movimiento hacia la predominancia de movimientos sociales que enfatizan los aspectos ideológicos de la movilización. Esta nueva tendencia invita a repensar los aspectos materiales de la movilización social. Desde el comienzo de la última crisis económica el tema de la vivienda y las movilizaciones en torno a ello han cobrado mucha importancia. En España, las ocupaciones de casas no habitadas han crecido rápidamente. Esta investigación describe el movimiento por la vivienda en Espańa 
y las ocupaciones como solución. Antes de la crisis económica, las ocupaciones estaban fundamentalmente relacionadas con el movimiento ocupa, pero ahora están más relacionadas con las luchas contra los desalojos. El artículo analiza específicamente casos en Sevilla y el movimiento Corralas.

Palabras clave: Nuevos Movimientos Sociales, Problema Urbano, Vivienda, Crisis, 15-M, Movimiento Ocupa.

\section{Introduction}

Spain has been greatly affected by the global economic crisis that began in 2007. This crisis has produced significant geopolitical and geo-economic changes, including economic collapse in European Mediterranean countries, with the region increasingly assuming a peripheral position in Europe and the western world. Changes in global position are reflected as changes in the internal structure of these countries. After several decades of modernization, economic growth and increasing social mobility, the peoples of these societies are now suffering from massive impoverishment and a degree of social polarization that only recently came to light. One issue best reflecting this situation is housing. Prior to the crisis, construction and housing were key sectors of the Spanish economy. During the same period, a large amount of vacant housing accumulated, with a strong tendency towards access to properties through indebtedness. With the economic crisis, thousands of unemployed households have not been able to pay their mortgages, resulting in eviction.

As the current housing bubble was being created, the squatting movement was one of a few criticizing real estate speculation -- the other criticisms mainly coming from ecological organizations. Squatters occupied vacant buildings to carry out their political demands. Squatting can be placed within what, since the seventies, has come to be known as the New Social Movements, aimed towards self management and the development of freer cultural practices and rebellious lifestyles. Since the crisis, families losing their homes have carried out large numbers of occupations, increasingly within a politics that calls for political changes that have positive material benefits for the new homeless.

The case of Spain is of special interest in examining differences in squatting movements before and after the onset of the 2007 economic crisis. This research work pays special attention to the case of Seville, where squatting has been carried out by working class families in a collective and public way since 2012. This work examines the change from ideological and youth squatters collectives to a popular movement, mainly composed of people newly impoverished by economic crisis. Information for the study comes mostly from participant research in the processes of organization and mobilization depicted, and the exploration of archives generated by the housing movement in Seville, as well as more commonly used sources (public statistics, newspapers and scientific papers). The purpose is to identify the relationship between the characteristics of the squatter mobilizations and the differing material factors in different contexts ${ }^{1}$.

\section{Background: Neoliberalism and Crisis}

At the global level, since the 'seventies, changes in the regulation of capitalism have had a significant effect on the urban environment. These effects have been diverse, although changes in the role of the State, financialisation of the economy, and changes in occupational structure, have special relevance (Amin 1994). The case of urban policy in Spain is no exception, with the development of housing, speculative bubbles, speculation in urban areas, and fragmentation of access to housing, all being important topics.

With regard to the first aspect, the regime that emerged from the 70s crisis appeals to flexibility and is characterized by intense levels of innovation, due to the emergence of new markets, and to financial deregulation, as well as the complexification of credit instruments (Harvey 1990). Harvey (1973, 1982) highlights the importance of credit and finance, and

1 This research was supported by the Spanish Ministry of Science and Innovation (CSO2011-23079) and the Program of Post-Doctoral Scholarships at UNAM 2012.The authors would like to thank to the $15 \mathrm{M}$ movement in Servilla, Juanjo García Marin materials and pictures and the support of Millie Wild. 
investment in fixed capital as a spatial solution to the economic crisis. In the case of Spain, these questions have tremendous significance, particularly due to the size of the housing construction sector. This cannot be understood without referring to the degree of ownership compared with rental, a trend that started in the sixties and seventies under the military dictatorship. During this period a significant intervention in the housing market aimed at increasing the ability of households to own their own homes (Capel 1983). In addition, the rental law was changed, discouraging landlords-capitalists from investing in buy-to-let properties. This led to increasing levels of private investment into the building of ownership housing (Lasarte 1996). As a result, in the early nineties, 80\% of households were owner-occupiers. The development of a huge construction sector was reinforced by the development of an economy highly dependent on tourism. The expansion of the tourist sector is clearly related to the first construction and real state economic boom occurring between 1962 and 1973. Urban development focused on the Mediterranean coast, mainly Cataluña, Baleares, Valencia and Andalusia. Financial and real-estate activity was controlled by foreign investors with the construction sector remaining in Spanish hands. During this period the percentage of workers employed in construction grew from $6.6 \%$ to $10.5 \%$ of the working population. In addition, between $15 \%$ and $22 \%$ of all foreign investment in the 1962-1973 period went to the purchase of real estate, (Observatorio Metropolitano, 2007 and Rodríguez-López and López-Hernández 2011). Some legal reforms during the dictatorship promoted the early growth of a secondary circuit of capital accumulation in real estate and finance. The Law of Zones of National Interest in Tourism (Ley de Centros y Zonas de Interés Turistico Nacional), in 1963, was the first liberalization experiment in the country, promoting the expansion of weekend or summer houses on the coast, and the first suburban clusters around main cities, with a wider expansion in the eighties and nineties (Observatorio Metropolitano, 2007, p. 184).
During the democratic period, reforms characteristic of the hegemonic neoliberal policy regime came into play, such as liberalization of the mortgage market, as well as the privatization of public banking. The State ceased to invest in the housing market and was replaced, in its role as a generator of demand, by the free market, acting through the facilitation of credit. Spain's entry into the European Economic Community occasioned two highly speculative real estate and financial cycles (Naredo 1998), during which a stock of close to 3.5 million vacant houses accumulated (Instituto Nacional de Estadística, Census 2011). There is some consensus on the general causes behind these cycles and on the high degree of importance of construction in Spain (see RodríguezLópez and López-Hernández 2011; Marsal and Vilanova 2013; Fernández-Tabales and Cruz 2013): (1) the maintenance of low interest rates that result in high levels of indebtedness by both households and companies; (2) the formation of the real estate and construction sector as the main national industry (along with tourism, linked to construction through promotion of hotels and second homes) promoting a period of elevated economic growth and low unemployment (which likewise stimulated demand); (3) state support given to the private construction sector through a variety of formulas; (4) foreign direct investment in property assets; and (5) the development of housing as an investment and speculative commodity.

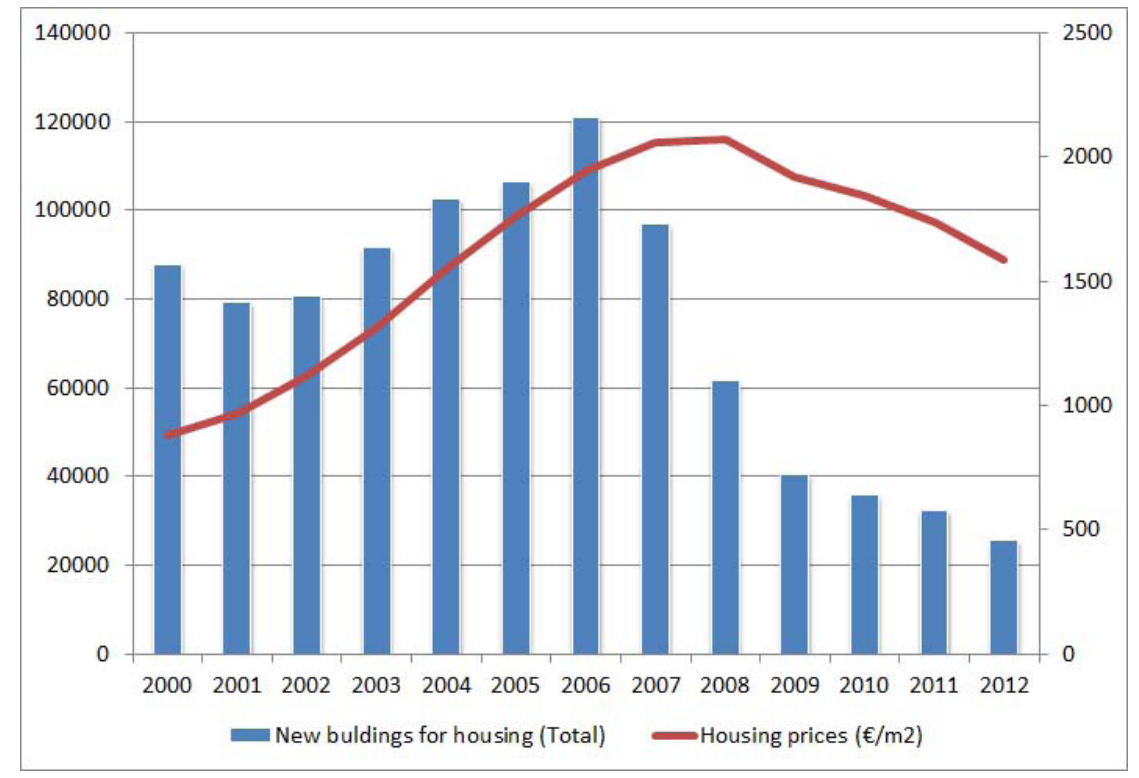

Figure 1: New building and housing prices. Source: Ministerio de Fomento, Spanish Government. 
During the last boom period, housing prices went up by between $10 \%$ and $20 \%$ (see figure 1 ). As result, the value of the nominal assets of families multiplied by 3.5 (Naredo, Carpintero and Marcos 2008).

Another fundamental characteristic of capitalism after the oil crisis is the greater importance assumed by local policies. These tend to focus on economic development, based on collaboration between public and private agents (Amin 1994, Jessop, 1995, Goodwin and Painter 1996). Some of the most recurrent strategies have been aimed at the urban renewal of historical centers, and at obsolete industrial enclaves. During the eighties, a set of plans proposing a return to the central city were developed in major Spanish cities. In the context of the housing bubbles, the main historical neighborhoods and old industrial zones saw large scale intervention. These areas had suffered marked decay during the previous decades, and were essentially inhabited by low-income people living in delapidated buildings, a high proportion of which were vacant and abandoned. Here, local administrations developed a strategy of intervention in public space and the construction of flagship projects that generated contagion effects in the private sector, which started to invest in rehabilitation or re-development construction (Tomé 2007 or Fernández-Salinas 1994). This, together with legal reforms, such as liberalization of tenancies in 1985, gave rise to intense processes of gentrification between the nineties and the housing bubble burst: the cases of Barcelona (Sargatal 2003) and Seville (Díaz-Parra 2009) are well known.

During the eighties and nineties, economic growth led to the consolidation of a homeowning middle class employed in the service sector, with the conciomitant appearance of job precariousness, primarily affecting youth (Tezanos 1984, 2002). From the late seventies on, dualization of the housing market became evident: the middle class enjoyed creditworthy demand; other social strata could not access the market and had to depend on public housing; while, meanwhile a stock of vacant housing began to emerge (Capel 1983). Dualization of the market intensified in the decades that followed, becoming particularly evident in the $21^{\text {st }}$ century. Young families could not buy houses due to high prices, while the assets of the middle classes were increasing, and the stock of vacant housing continued to grow (Díaz 2003 or Colau and Alemany 2012). It is important to examine how the housing issue affects groups that continued renting in the urban centers. The issue of an influx of foreign immigrants from the nineties on, or the survival of substandard housing in some undermaintained sectors of the working class peripheries of cities, usually problematic, was unknown to a middle class that had gained a significant importance in the social structure.

This situation would change rapidly. Periods of boom had left a strong dependency on the construction sector; a stock of millions of vacant homes; and some tremendously over-valued real estate assets. The international financial crisis caused a credit crunch, which first affected the construction sector. Mass layoffs and impoverishment started to be felt. The contagion of layoffs to other sectors meant that that Spain surpassed 6 million unemployed, with unemployment rates rising to over 26\% (see Encuesta de Población Activa, Instituto Nacional de Estadistica). Furthermore, the fall in housing prices left families with unsupportable indebtedness acquired in previous years.

The combination of unemployment, collapse of property prices, and legislation that does not cancel the debt if homeowners return the property when in negative equity, leaves indebted families without housing when they cannot continue paying their mortgages. In 2012, there were more than 100,000 evictions in Spain (data published by the General Council of the Judiciary of Spain). The distribution of evictions and unemployment shows a strong concentration in the main cities and in touristic areas of the Mediterranean and southern Spain - regions that are highly dependent on tourism and construction, in contrast to the more diversified economy in northern Spain (See figure 2).

\section{Crisis of labor and the new social movements}

In Spain crisis in the labor movement is produced in parallel to, but in a different form from, the more general western context. Fierce repression by the Franco dictatorship (Preston 2011) did serious damage to the 


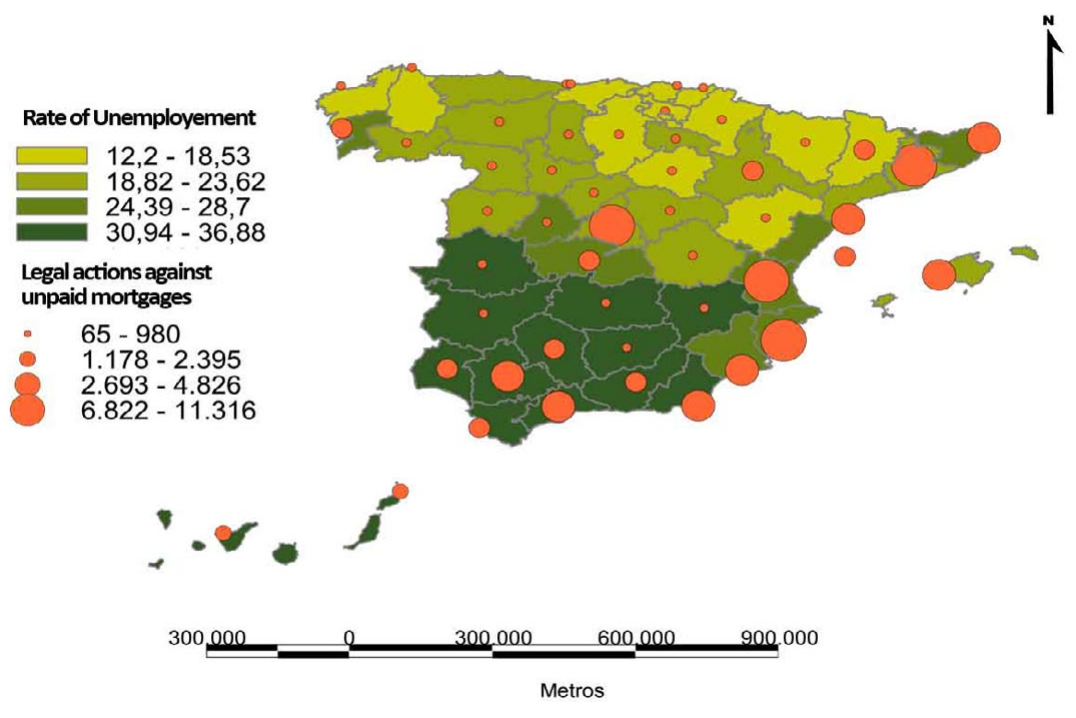

Figure 2: Unemployment and legal actions due to unpaid mortgages, 2012. Source: Instituto Nacional de Estadística and General Council of the Judiciary of Spain (Spanish), 2012. other words, identity, autonomy, and recognition would be sought, instead of material resources or power.

Nevertheless, 1968, usually seen as a tipping point in the transition from the classic labor movement to the culture of new movements, had limited influence in Spain, occurring mainly among student groups. Meanwhile, during the fight against the dictatorship throughout the seventies, the union and labor movements continued to have remarkable weight. One of the most outstanding aspects would be the transfer of struggles from spaces of production to urban areas, most notably with the emergence of neighborhood associations (Castells 1983 and 1977). revolutionary culture, mainly anarchist, of the Spanish labor movement before the Civil War. Although there was a resurgence of syndicalism during the period of transition to a liberal democracy, and class discourses were taken up again, they did not have the thrust of the prewar movements, due to both severe repression by Franco as well as a trend towards the decline of the labor ideology as with the rest of the western world.

As a result of profound events from the 1960s onwards the structure of the working class changed, with a decline in the proportion of blue collar workers and laborers. Polarization and class opposition, typical of Marxism, would be more the product of the liberal-industrial capitalism of the $19^{\text {th }}$ century in Western Europe than $20^{\text {th }}$ century reality (Touraine 1973:14-21). At the same time, the emergence of new movements in the sixties and seventies, clearly distinguishable from the classic labor movement, would give rise to new explanatory theories, such as the new social movements theory. For Melucci (1989, 1999) new social movements derive from accelerated changes in complex societies. For the new social movements, seizing the State lost its meaning (Holloway 2002). Instead they sought to transform society through the modification of political power, focussing their main activities in the cultural or contractual terrains. In
Only in the eighties did youth movements gain prominence in the new mobilizations, providing a marked countercultural emphasis, which would expand across the country along with liberal democracy. The arrival of democracy, and the ascent of the center-left parties to power, resulted in demobilization and progressive co-optation of workers' organizations, both unions and neighborhood associations. In response, mobilizations by the younger generations (who had not participated in the transition process from the dictatorship to liberal democracy) began to dissociate from the protection of leftist political parties and the institutions of the labor movement, progressively entering into the world of new social movements reigning in Europe. This political space would be inevitably marked by the weakening of the labor movement, the fall of the Berlin Wall, and the global hegemony of neoliberalism. So the mobilization cycles increasingly acquired a heavily ideologized character. Some movements managed to maintain a broad and a certain level of social support, particularly the students movement, or the protests against compulsory military service. Others moved further away from institutional politics, with an increasingly more identity-focused character, once the communication channels between the radical left and popular masses 
had disappeared, such as in the cases of anti-fascist action and the squatting movement.

From the late nineties, the new movements acquired a more inclusive and progressively citizenismfocused character. In this sense, the influence of the Zapatistas on youth movements would be marked. These practices and discourses had an unquestionable impact on social movements in Spain in the second half of the nineties, similar to the rest of the western world, closely related to the anti-globalization movement. Some authors distinguish mobilizations generated within this context with previous ones, talking in some cases of "newest social movements" (NsMS, for its acronym in Spanish) (López and Sánchez 2005; Pastor 2006; Ibarra 2005) or "new global movements" (Calle 2005). The newest social movements are characterized, on the one hand, by globalization, not in a territorial sense, but in terms of broad themes and demands, in opposition to the fragmentary demands of the new social movements of the seventies and eighties. On the other hand, the economy once again became an important element in the discourse, mainly in terms of critiques of neoliberalism and social dispossession; although nevertheless it did not reach the central role it had with the labor movement.

\section{From the squatting movement to the $15-\mathrm{M}$ and the movement for housing. The case of Seville.}

\section{The squatting movement}

The rise of the squatting movement in Spain was influenced by previous experiences in countries such as Germany, the Netherlands, the United Kingdom and Italy (Pruijt 2003; Martínez-López 2011). The practice of occupying social centers and houses extended throughout Spain between the late eighties and early nineties (the squatted social centers model, used for youth leisure, artistic workshop and/or citizen participation, was imported mainly from Netherlands and Italian Centri Sociali). The main centers were located in Madrid and Barcelona. Similar occupations occured in many other cities like Seville or Valencia. Nevertheless, it was only in Barcelona where the movement acquired relevant and long-lasting size and social influence.

Political ideas lean between a sort of anarchism, which disassociates itself from syndicalist union strategies of libertarian communism, and an imported autonomism that is clearly defined in the Barcelona of the late eighties, with similar experiences in the Coordinadora de Colectivos Lucha Autónoma in Madrid, and the Kasal Popular in Valencia. Here, autonomy would imply a certain level of eclecticism between collectivities that came from the radical left and collectivities stemming from a more genuinely anarchist tradition (Adell and Martínez-López 2004:135). This coincides with the afore-mentioned bursting of the "new social movements" onto the scene in Spain. The real contents of the movement can be discerned in its decentralized organizational forms and in practices based on direct action. The critiques of the evolution of the labor movement lead them to locate themselves in a scenario of confrontation with the local administration, where possibilities for negotiation are discarded as a point of principle. In this context, occupation of social centers constituted a fundamental tool, both for the squatting movement, and for the "new social movements" in general (Martínez-López 2007).

During the second half of the nineties, some of the most powerful campaigns used by Spanish social movements lost strength (with the disappearance of compulsory military service as determining factor) and so a significant re-focussing of energies on social centers took place. At the same time, the movement underwent fierce political repression, with the hardening of laws against occupation, and strong stigmatization generated by the media (Adell 2007:26; Adell and Martínez-López 2004). In this context squatting movement increasingly acquired characteristics of cultural identity, focused on counterculture and self-management, highlighting their differences and in some cases provoking their stigmatization (Adell and Martinez-López 2004:179-182, Dieste and Pueyo 2003 or (Domínguez, Martínez and Lorenzi 2010:11).

In Seville, the earliest squatting movement groups came into being at the end of the eighties and beginning 
of the nineties. The squatted and self-managed social center Cruz Verde, between 1991 and 1995, was especially influential. The squats were important as support for political campaigns (against compulsory military service, speculation and some other issues) and for the introduction of new ideological frameworks and aesthetics related to the new social movements. This was a localized movement, settled basically in the old working class quarters of the historical city center, places in deep urban and demographic decline, and also possessing strong symbolic capital.

Fierce repression made the squatting movement nearly disappear in the city in the second part of the nineties. Despite that, between 2001 and 2011 a second wave of squatted social centers arose. One of the main reference points in this period is the squatted and self-managed social center Casas Viejas. A few others with similar characteristics followed, but after 2010 the movement again declined, with severe repression directed against militants, old social centers dismantled, and new squats quickly evicted. The ideology and the aesthetics of this second wave were not substantially different from the original movement, even though they did become involved with neighborhood and housing struggles, especially those related to the fight against gentrification (DíazParra 2010).

\section{Occupied centers and urban space}

Urban occupations, from the late eighties on, were framed by the creation of an enormous real surplus of housing with the successive speculative real estate cycles and restructuring of historical centers and decining industrial areas. During this period, the number of empty homes reached extremely high levels (14\% of the total housing stock according to the Instituto Nacional de Estadistica). These elements provided the initiating material, and the environmental scene, in which occupation was developed as a critical response to speculation, configured as a juvenile phenomenon where occupation of social centers had more weight than occupation of housing (Martínez-López 2003).

On the other hand, during the boom, there occurred a definite restructuring of historical centers and old obsolete industrial areas squeezed into the consolidated city. During the eighties and even the nineties, a large section of historical city centers remained in a state of extreme abandonment, with a large portion of the rented accomodation and vacant housing of large cities there, as well as buildings in disrepair. At the same time, the reassessment of a considerable portion of industrial spaces near the historical city center was still pending. These spaces offered unbeatable opportunities both for occupation, due to the large amount of available buildings and the existence of structures particularly suitable for collective use (factories, warehouses), and also for speculation, in the face of evidence of potential investment and disinvestment flows in different fronts of the city that would end up producing gentrification and displacement. In this context, occupations aimed at slowing down the decay of some buildings (and of the neighborhood), through occupation and partial reinstatement (some cases for Seville are collected in Díaz-Parra 2008).

Depreciation and demographic decay of these types of urban sectors allowed the formation of countercultural enclaves and local activist networks around squatted social centers, for example in the Lavapiés (Madrid), Gracia (Barcelona) or Alameda (Seville) neighborhoods.

\section{5-M and new struggles for housing}

$15-\mathrm{M}$, also called the indignados movement, is a citizen's movement born from massive demonstrations on May 15, 2011 and organized through social networks, in the context of the economic crisis. The first demonstrations resulted in the occupation of public space in Puerta del Sol (one of Madrid's main squares) followed by similar occupations in major Spanish cities (including Seville). The civil disobedience of the movement was in defiance of the main Spanish political parties, Partido Popular (cristian-democrats) and Partido Socialista Obrero Español (social-democrats), as well as the power of financial institutions, demanding more participative democracy (obviously, the $15 \mathrm{M}$ movement shares the context and some characteristics with other contemporaneous movements around the world, such as Occupy movement in 
EEUU or Yosoy132 in México). After the occupation, neighborhood and town 15-M movement assemblies were created all over Spain, many of which remain in existence today (Díaz-Parra and Candón, 2014). The movement represents a tipping point in the social response to the crisis and will subsequently decisively drive local struggles all over the country.

During the most fertile period of 15-M, previously existing networks of neighborhood assemblies were fed by mobilizations, or were newly created, at least in Seville, Madrid and Barcelona. In response to critiques of the representative democratic system, the movement

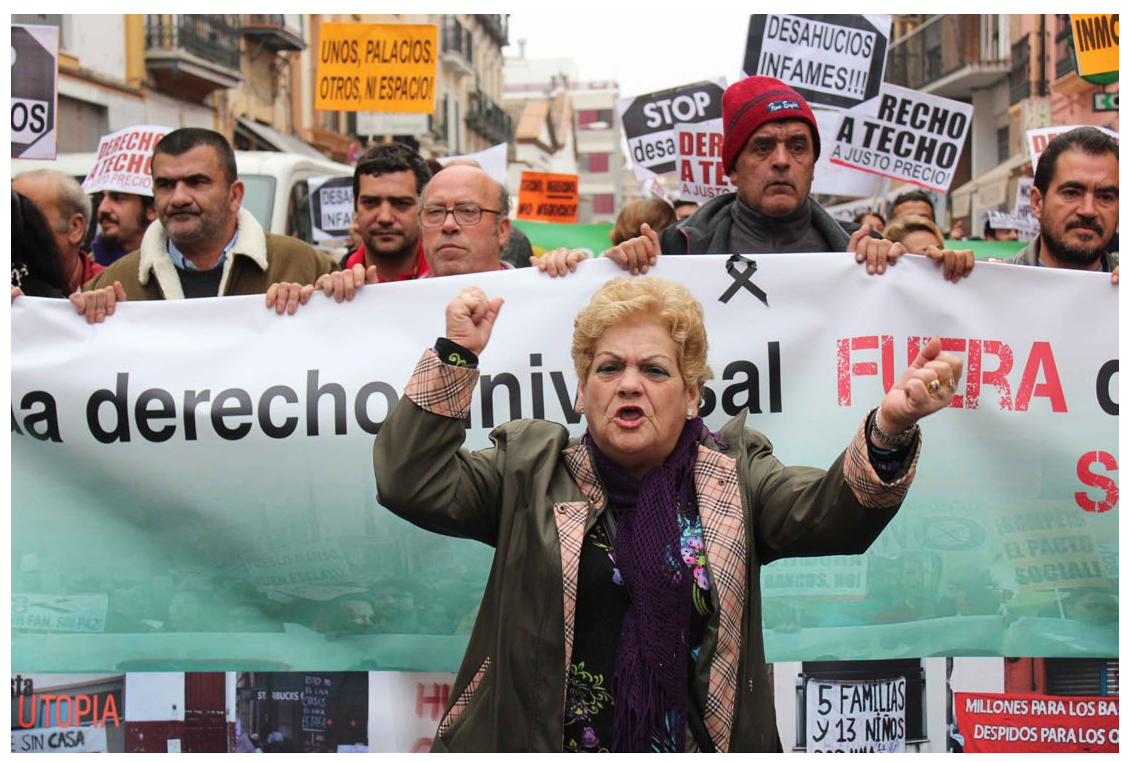

Figure 3: Demonstration against evictions in Seville. Source: Juanjo García Marín, 2012. decentralized itself into small assemblies located in neighborhoods. Moreover, decentralization made young activists meet with the specific social realities provoked by crisis. Neighborhood assemblies contacted those under threat of eviction, enabling their participation in the movement. The resistance to evictions spread, and the movement used its force and accumulated legitimacy to fight against what was perceived as injustices perpetrated against the population. Here, the 15-M movement fed into the Plataforma de Afectados por la Hipoteca (PAH), an organization whose origin lies in the 2006 movement for housing, but gained special relevance in the new context generated in 2011. At the national level, 15-M would ally with the PAH to stop the first eviction of this new mobilization wave in Madrid in June 15th, 2011. During that week, civil disobedience thwarted eight housing eviction orders in several cities². This practice would be disseminated and multiplied all over the country in the following two years and lasting to the present day.

On the other hand, at the beginning, in some cities, the movement used previously squatted social centers, related to the old squatting movement (at least that was the case of Madrid and Malaga). However,

2 Público (journal), 18-06-2011, "Los indignados se lanzan al rescate de los desahuciados”. [http://www.publico.es/ espana/382602/los-indignados-se-lanzan-al-rescate-de-los-desahuciados].

the movement would start to create its own spaces of reference through the taking of vacant buildings, evidencing, in some cases, attempts to substitute for the square as a common geographical space of reference at the city level, the cases of Cádiz (Valcárcel) and Madrid (Hotel Madrid). In the newly squatted social centers, the use of the word "taking" or "recovering" instead of "squatting" denotes an intention to assume the $15-\mathrm{M}$ as a strategic identity, in contrast to the stigmatized "squatters" identity. After a first wave of occupations related to 15-M (in Madrid, Barcelona, Zaragoza, Cádiz, and Seville), the most recent occupations of social centers show the progressive consolidation of the movement in some working class neighborhoods (Banco Güeno, occupied in Malaga in 2012, or La Soleá, in Seville in 2013, both located in peripheral working class neighborhoods of public housing). On the other hand, the first occupations in Madrid, early frustrated by eviction, began to connect with the tactics of intervention on the evictions by occupying in order to rehouse people in large numbers, which would start to gain strength particularly in 2012 .

The logical continuation of the resistance to evictions was the rehousing actions through occupation of abandoned spaces or houses appropriated by banks and savings banks ${ }^{3}$. Mass squatting in Andalusia supported by the $15-\mathrm{M}$ movement is particularly

3 See for example: El País (journal), 19-2-2012. 
relevant and is described in the next epigraph. The Plataforma de Afectados por la Hipoteca, on the other hand, launched in 2013 a new campaign named Obra Social, which occupies vacant buildings owned by banks, occurring specifically in Catalonia. In this region, between the assemblies of the 15-M and the $\mathrm{PAH}$, there are up to eight blocks of empty, or newly constructed, flats.

Outside these type of actions, the most influential demand, championed by the $\mathrm{PAH}$, has been the change of the mortgage law to permit the handing over of the seized flats in exchange for writing off the debt. For the last two years, the struggle of the movement for housing has gone in this direction, with the public debate having major resonance and implementing a variety of tactics, such as escraches, in which those affected by the housing crisis harassed politicians in their own homes who were in charge of voting on the housing laws ${ }^{4}$. Furthermore, the institutional way has been tried, with the presentation of a Popular Legislative Initiative (ILP, for its acronym in Spanish) admitted to process as a result of social pressure, but ultimately rejected by the Parliament by the majority of the ruling party (Partido Popular). The prominence of this demand, the main point of consensus of the movement, reflects both the materiality of the issue as well as the political dimension of the sought solution.

\section{Collective squatting in Seville: The Corralas.}

In Seville, after the May 15 of 2011 mobilizations, a web of neighborhood assemblies was created, covering the main districts of the city and the metropolitan area. The old activists and previous organizations, related to grassroots movements and housing, mixed with a new generation of mobilized subjects. The most significant formal structure emerging from the movement, besides the neighborhood assemblies, was the housing commission of the Seville 15-M. This institution was first created for the coordination of assemblies around housing struggle. New activists met there with a considerable collection of old militants, experienced in housing struggles, neighborhood asso-

4 El Diario (journal), 11/05/013 [http://www.eldiario.es/ catalunya/economia/Rajoy-escrache-PAH-iniciativa-legislativa_0_130887501.html]. ciations, tenants' movement and squatting movement. So, after 2011, it became the main coordination of Seville activism around the housing question.

The housing commission carried out its first public action, a demonstration against evictions in October. The event culminated in the taking of a building, planned as a social center for the movement. Unfortunately, the installation was evacuated before it could really be used. Nevertheless, since July of 2011, the $15 \mathrm{M}$ had been calling for resistance to the evictions of families. In 2011 and 2012, these kinds of actions were mainly carried out by the housing commission (since 2012 Seville's PAH has gained in importance). Especially significant was the prevention of the eviction of a family in December 2012, in a working class peripheral area in Seville. Strong support from the neighborhood for the resistance, organized by $15 \mathrm{M}$ activists, made the police abandon the eviction. Similar actions continue up to the present day in working class districts of the city.

On February, 2012, the housing commission created a web of advisory offices for housing in the metropolitan area of Seville. The offices were supported by the $15 \mathrm{M}$ neighborhood assemblies, usually using the old neighboorhod association or some other allied association's space. The offices, each managed by a volunteer lawyer and some activists, support families menaced by eviction for unpaid rents or mortgages, or newly homeless after an eviction. Families began to group around the offices, to force negotiation with credit institutions, stop evictions and, after some time, to organize collective squats.

Information obtained from the housing commission reveals how the housing problem mainly affects the working class districts in the city. Figure 4 shows evictions due to non-payment of mortgages in the last term of 2011. The cases concentrate in areas of higher unemployment, the working class peripheral ring of the city in the north, east and southeast. Thus, the profile of the families supported by the advisory offices is predominantly working class, manual workers around 30-35 years old, with children and low levels of qualification ${ }^{5}$. Previously these families tended to

5 The main differences with social composition in Madrid 


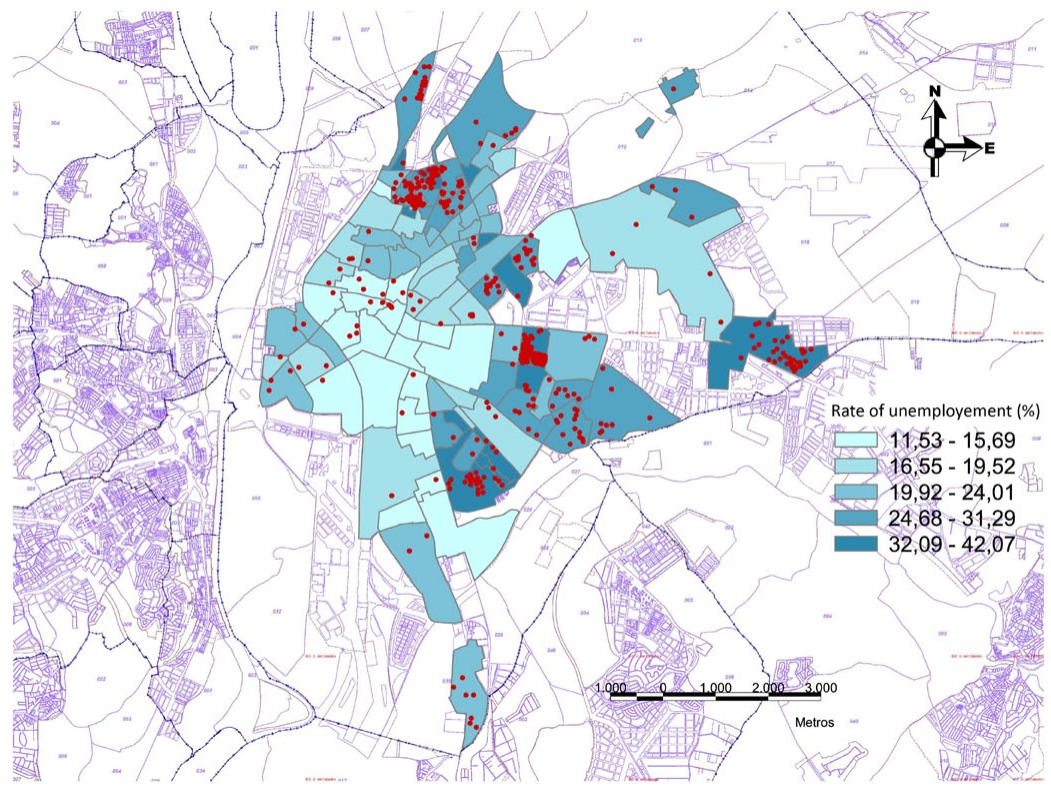

Figure 4: Distribution of evictions and rate of unemployment in Seville. Source: 15M housing advisory offices, 2012.

have stable salaries, enough to enable them to take on debt to obtain a home. After losing their jobs, they stop paying the mortgage (the majority) or the rent. Thus, the $15 \mathrm{M}$ movement, initially visibly déclassé, became progressively working class.

Soon, the new housing movement used the extensive experience of the long term squatting movement activists for organizing collective squatting. The families begun to take empty new buildings, part of the non-sellable stock of houses created by the crisis, usually owned by big banks.

In May of 2012, in Seville, 38 families occupied 4 vacant buildings, owned by a bank (Ibercaja), naming the complex La Utopia. The group of families was created in the advisory office and supported by the $15 \mathrm{M}$ assembly of Macarena (a working class district in the north of Seville). The group had previously undergone a period of preparation, which lasted months, where the families were advised and helped by activists from the neighborhood and squatting movements. In the months that followed, up to three buildings were also squatted in the center of Seville, and another nine in the urban area were occupied, accommodating more than 200 families. Furthermore, multiple individual and non-advertised occupations took place, supported by the structure of neighborhood assemblies of the 15-M. Later, the model spread to other Andalusian cities, with up to four mass occupations in Malaga, two in Granada and the occupation of a neighborhood by 164 families in Huelva. The social profile was of working class families (with children), who had lost their jobs and had been evicted from their homes. There was also a minority profile of impoverished middle classes. In some cases, the families demanded affordable housing from the central or local government. Those working class popular squatters have had wide social influence

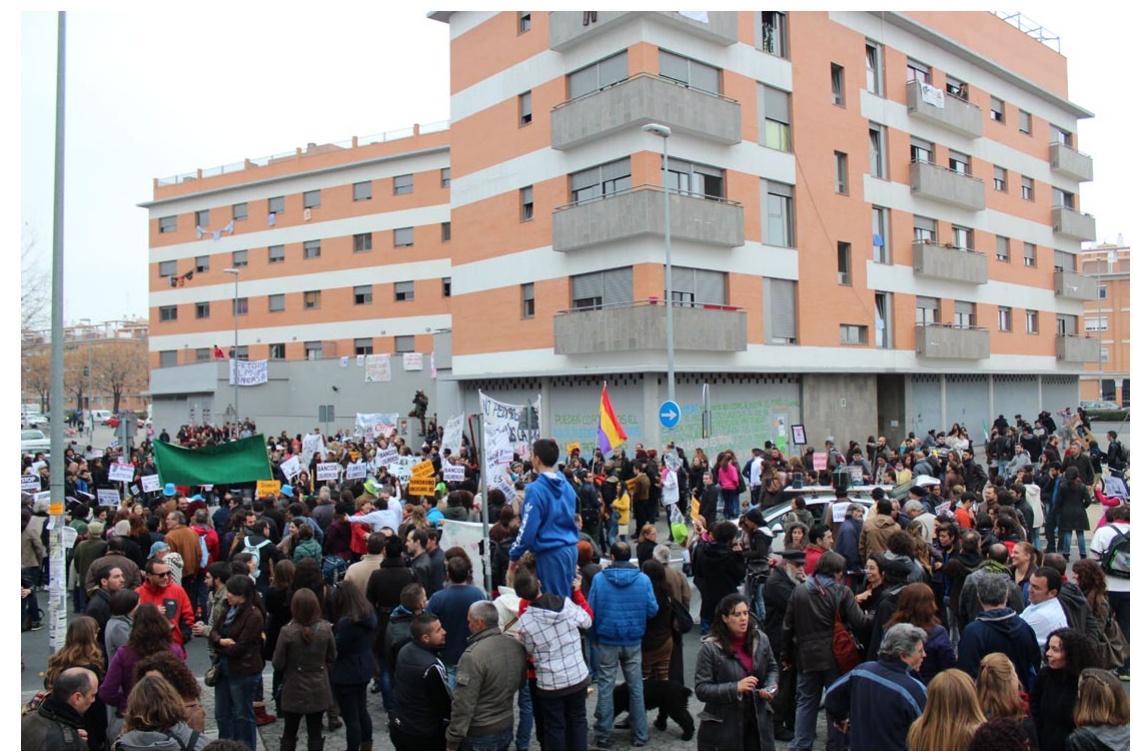

Figure 5: Corrala Utopía. Source: Juanjo García Marín, 2012. or Barcelona are related to the higher rates of unemployement, average over 33\% last two years (Encuesta de Población Activa, Instituto Nacional de Estadistica) and the lower weight of foreign-immigrant population, always below $5 \%$ of the population in the last decades (Instituto de Estadistica y Cartografía de Andalucía). and impact on the media, with Corrala Utopia the undoubted flagship of the movement ${ }^{6}$.

6 Some articles and news can be checked: El País "Un año refugiados en la Utopía” [http://ccaa.elpais.com/ ccaa/2013/05/17/andalucia/1368817383_528335.html], 


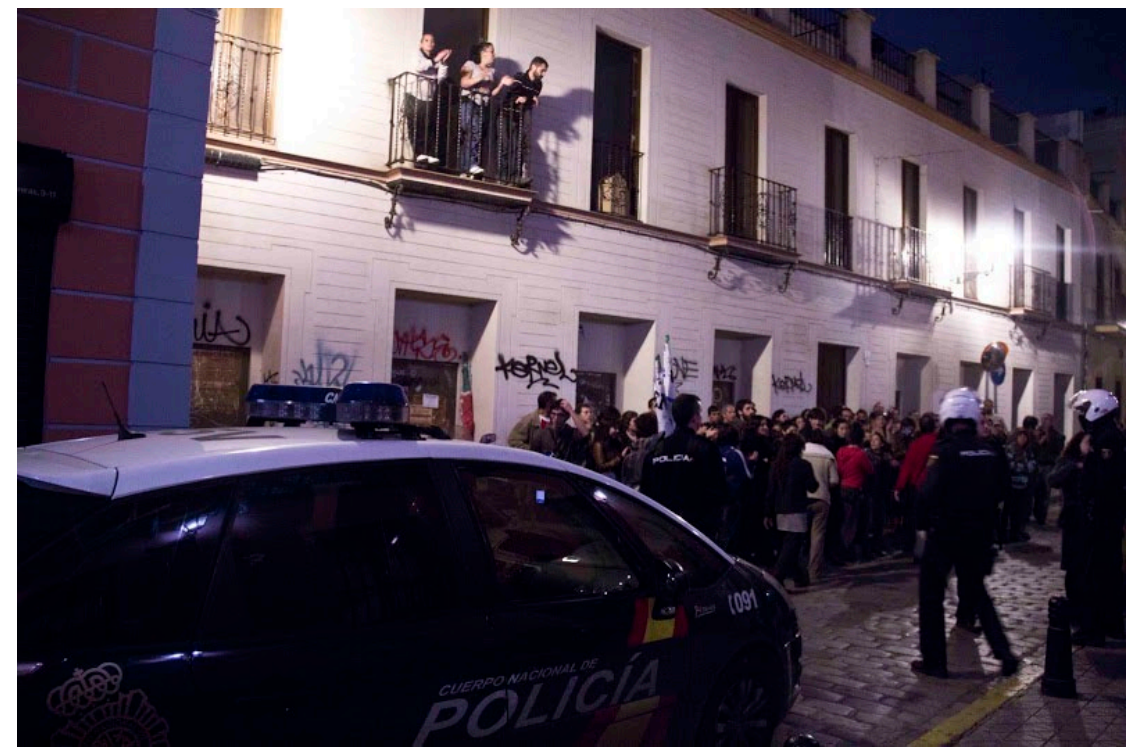

Figure 6: Families squatting. Source: Haze Ina, 2012.

The term corrala refers to the historic rented houses typical of Andalusia. It has been the most visible action of the housing movement in the south. The movement in southern Spain began to coordinate amongst themselves after the summer of 2012, integrating the aforementioned housing commission of $15 \mathrm{M}$ Seville and local platforms against evictions and the PAHs from other cities of Andalusia.

Currently the three corralas in the historical city center have been evicted, as well as Corrala Utopía, and nine groups of families are in an uncertain situation (see figure 7). The families of Corrala Utopia resisted for nearly two years without water or electricity. In spite of the negotiations with the bank that owns the building, and the Andalusian government, the families were evicted, in April 2014, by the police on behalf of the bank Ibercaja. The Andalusian government was forced to rehouse most of the evicted

\footnotetext{
New York Times "Wave of evictions leads to Homeless Crisis in Spain" [http://mobile.nytimes.com/2012/11/12/world/ europe/spain-evictions-create-an-austerity-homeless-crisis. html], El Mundo "Famlias de la Corrala Utopía duermen ante Ibercaja para que cumpla” [http://www.elmundo.es/elmundo/2012/11/16/andalucia_sevilla/1353095335.html], The Guardian "How the corralas movement is occupying Spain" [http://www.theguardian.com/world/2013/mar/04/corralamovement-occupying-spain], ABC "Cuando ocupar se escribe sin k" [http://www.abcdesevilla.es/20120520/sevilla/sevi-cuando-ocupar-escribe-201205192240.html].
}

families in social houses with low rents ${ }^{7}$. Besides Corrala Utopía, only two corralas were successful in coming to an arrangement with the landlords to provide low rent accomodation for the families.

The dynamism of the housing movement in Andalusia has forced the regional government to take measures. The Andalusian government has been social democrat (PSOE) since its creation in the political transition to liberal democracy. The housing politics were quite similar to national ones, privatization of the public housing stock, support to the free housing market and urban renewal in the most degraded areas (such as in Polígono Sur in Seville, see Torres, 2013). After the 2012 regional elections, the new government was a coalition among left wing parties, the social democrats of PSOE as well as leftists and communist of Izquierda Unida, who were given responsibility for housing policy. The overall context of compulsory austerity has limited the impact of any changes. Public housing privatization has been stopped (a long term demand of the housing movement) and the promotion of owner occupation has been replaced with rented social housing (even if the construction of new housing has been minimal in the last few years). Beside this, Andalusia Government has created its own institutional web of advisory offices, clearly a copy of the housing movement offices. The most important measure was the creation of a Law, in 2013, which promised the expropriation of empty houses and repossessed houses where families were in risk of been evicted from their only house. In the last years only two houses have been effectively expropriated, and legal procedures begun for nearly forty houses ${ }^{8}$. The lack of real impact of the new law has been partially the consequence of its suspension

$7 \quad$ See Publico (paper) "El desalojo de la Corrala Utopía fue casi militar" 7/4/2014 [http://www.publico.es/actualidad/512885/el-desalojo-de-la-corrala-utopia-fue-casi-militar], El Diario (paper) "Fomento asume el relalojo de las familias" 9/04/2014 [http://www.eldiario.es/andalucia/Junta-Andaluciafamilias-Corrala-Utopia_0_247775380.html]

8 See Junta de Andalucía (press note) "La Junta solicitará al Constitucional el levantamiento urgente de la suspension cautelar de la Ley tras el recurso del Gobierno" 17/01/2014, [http:// www.juntadeandalucia.es/fomentoyvivienda/portal-web/web/ noticias/1ad46314-7f4e-11e3-bae6-5108384b14f9]. 


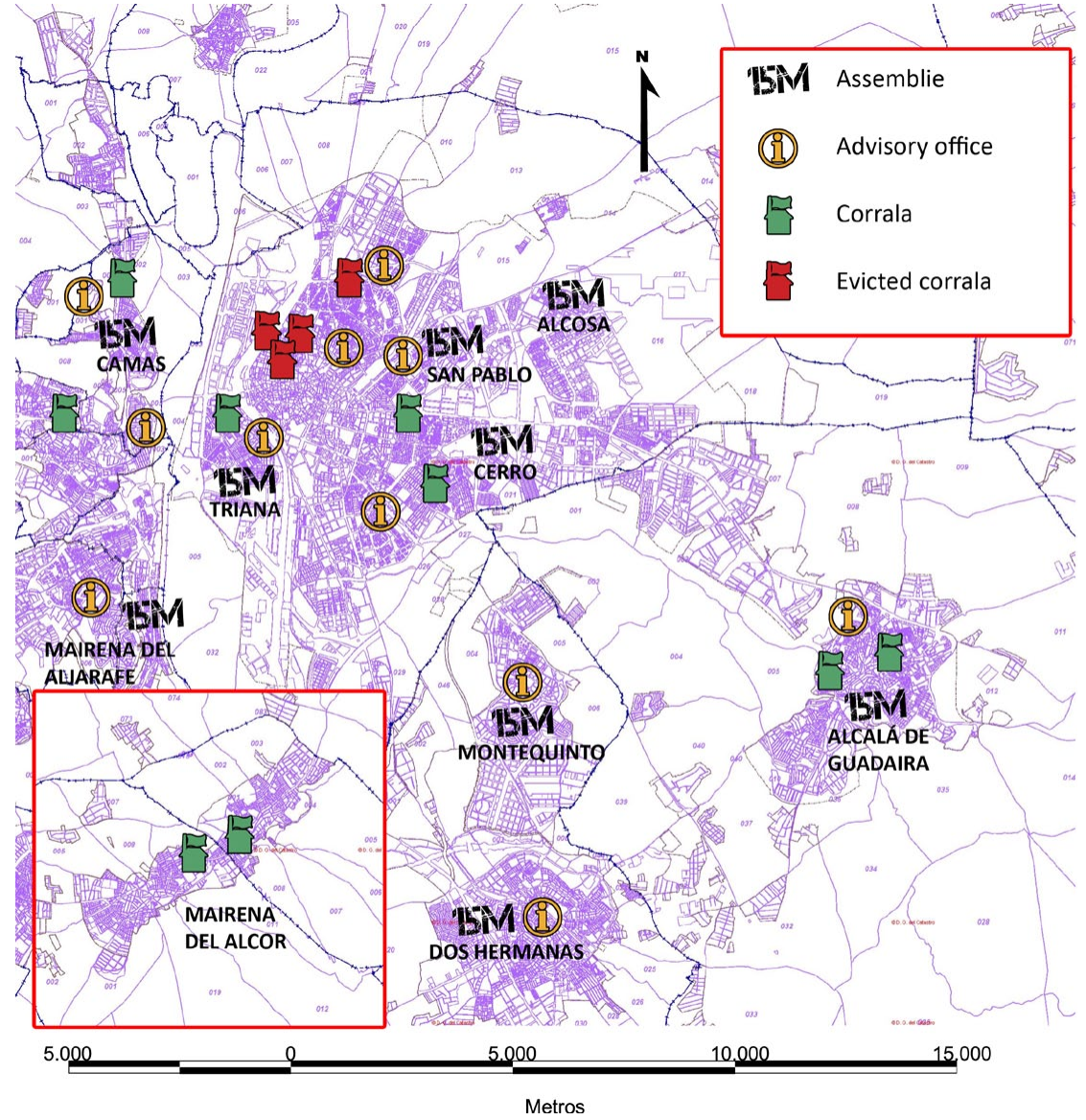

Figure 7. Corralas and advisory offices in the Seville Metropolitan Area. Source: Self-elaborated.

by the Constitutional Court, after the central government appealed against the measure due to its risk for the economy ${ }^{9}$.

\section{Conclusions}

This essay demonstrates that struggles related to the housing issue, and the occupation phenomenon, in Spain have been transformed, particularly since the beginning of the crisis in 2007.

Structural aspects influence the squatting movement, as well as the current housing movement, in different ways. Changes in the economic structure throughout the 20th century have produced changes in the nature of urban and housing issues. In turn, the shape of urban social movements is (partially) condi-

9 See El Diario (paper) "El recurso del Gobierno: la Ley antidesahucios pone en riesgo la economía de España" 29/1/2014 [http://www.eldiario.es/andalucia/Ley-Funcion-Social-Vivienda-economia_0_223277817.html]. tioned by urban processes and structures. Squatting in Spain is a good example of the former. It has been shown how the urban environment influences the shape of the squatting movement, mainly as a framework of opportunities and obstacles. An explanation of the squatter movement must take into consideration the ideological-cultural aspects, particularly the strongly identify-centered youth counterculture of the eighties and nineties in Spain. This movement is also a product of its material context, which is the defeat of the labor movement and the consolidation of an affluent society in Spain.

The subsequent evolution of the struggle for housing and occupation as a form of grassroots action is highly influenced by material factors. Again, in the urban context, the collapse of the construction sector, and the vast stock of vacant houses accumulated by banks, become a framework of opportunities. Also, the mortgage crisis creates a mass of affected people, evicted individuals who, mainly motivated by their own objective situation, turn towards activism, and carry out occupations. This has a broad impact on the working class neighborhoods of the major cities, where the lower classes are the main victims of the economic crisis.

The current movement for housing is clearly supported by practices and discourses generated by social movements such as the squatting movement. The existence of previous networks made it possible for crisis victims to move quickly from dissatisfaction to mobilization. However, current movements differ substantially from those before the Spanish crisis. The current housing movement has widespread support, mobilization responds to material needs, and interaction with political institutions is necessary to attain the movement's goals.

The strong ideological and cultural motivations of the old squatting movement is (partially) a product of 
a context of low social conflict, high social mobility and material welfare and defeat of anti-systemic movements. However, when progress vanishes and material discomfort spreads, this once again becomes a basic element of grassroots mobilization. Thus, the new context presents an opportunity for the reemergence of class politics.

\section{References}

Adell R (2007) La Vivienda Sí Preocupa. Ocupantes y Ocupaciones. Libre pensamiento 54: 24-31.

Adell R and Martínez-López M (2004) ¿Dónde Están las Llaves? El Movimiento Ocupa: Prácticas y Contextos Sociales. Madrid: Los Libros de la Catarata.

Amin A (1994) Postfordism. A Reader. Oxfod: Blackwell.

Calle A (2005) Nuevos Movimientos Globales. Hacia la Radicalidad Democrática. Madrid: Popular.

Capel H (1983) Capitalismo y morfología urbana. Barcelona: Universidad de Barcelona.

Castells M (1977) The Urban Question: A Marxist Approach. London: Edward Arnold.

Castells M (1983) The City and the Grassroots: A Cross-Cultural Theory of Urban Social Movements. Berkeley: University of California Press.

Colau A and Alemany A (2012) Vidas Hipotecadas. Barcelona: Angle editorial.

Díaz-Parra I (2010) Sevilla, cuestión de clase. Una geografía social de la ciudad. Sevilla: Atrapasueños.

Díaz-Parra I (2009) Procesos de Gentrificación en Sevilla en la Coyuntura Reciente. Scripta Nova: Revista Electrónica de Geografía y Ciencias Sociales 304(13).

Díaz-Parra I (2008) Movimientos Vecinales Contra la Gentrificación y Transformaciones en la Política Local de Sevilla. Los Casos del Pumarejo y San Bernardo. Actas X Coloquio internacional de Geocritica. Barcelona: Universidad de Barcelona.
Díaz-Parra I and Candón J (2014) Espacio geográfico y ciberespacio en el movimiento 15M. Scripta Nova. Revista Electrónica de Geografía y Ciencias Sociales 470(18).

Díaz C (2003) La Vivienda en España, Reflexiones Sobre un Desencuentro. Scripta Nova. Revista electrónica de geografía y ciencias sociales 146(095).

Dieste J and Pueyo A (2003) Procesos de Regeneración en el Espacio Urbano por las Iniciativas de Autogestión y Ocupación. Scripta Nova. Revista electrónica de geografía y ciencias sociales 146(108).

Domínguez M, Martínez M and Lorenzi E (2010) Ocupaciones en Movimiento. Derivas, Estrategias y Prácticas. Madrid: Tierradenadie Ediciones.

Fernández-Salinas V (1994) Los Centros Históricos en la Evolución de la Ciudad Europea desde los Años Setenta. ERIA 74: 121-131.

Fernández-Tabales A and Cruz E (2013) Análisis Territorial del Crecimiento y la Crisis del Sector de la Construcción en España y la Comunidad Autónoma de Andalucía. Eure 116(39).

Goodwin M and Painter J (1996) Local Governance, the Crises of Fordism and the Changing Geographies of Regulation. Transactions of the Institute of British Geographers 2(4): 635-648.

Harvey D (1990) The Condition of Postmodernity: An Enquiry into the Origins of Cultural Change. Oxford: Blackwell.

Harvey D (1982) The limits to Capital. Oxford: Blackwell.

Harvey D (1973) Social Justice and the City. Baltimore: Johns Hopkins University Press.

Holloway J (2002) Change the World Without Taking Power: The Meaning of Revolution Today. London: Pluto Press.

Ibarra P (2005) Manual de sociedad civil y movimientos sociales. Madrid: Síntesis. 
Jessop B (1995) The Regulation Approach, Governance, and Post-Fordism: Alternative Perspectives on Economic and Political Change? Economy and Society 24(3): 307-333.

Lasarte C (1996) Comentarios a la Ley de Arrendamientos Urbanos. Madrid: Tecnos.

López S and Sánchez I (2005) "Los imaginarios de internet: una aproximación crítica a los discursos hegemónicos en el ciberespacio", en Nómadas, enerojunio, número 11. Universidad Complutense de Madrid.

Marsal M L and Vilanova J M (2013) Hegemonía y Declive de un Ciclo Desarrollista Ya Destronado. Urbanismo y Construcción en España 1997-2007. Biblio 3W. Revista Bibliográfica de Geografía y Ciencias Sociales 1015(18).

Martínez-López M (2011): “The Struggle for Social Autonomy: What Have We Learnt about Urban Politics from Squatting in Europe?". The struggle to belong Dealing with diversity in 21st century urban settings Amsterdam.

Martínez-López M (2007) El Movimiento de Ocupaciones: Contracultura Urbana y Dinámicas Alter-Globalización. Revista de Estudios de Juventud 76.

Martínez-López M (2003) Viviendas y Centros Sociales en el Movimiento de Ocupaciones. Scripta Nova. Revista electrónica de geografía y ciencias sociales 146(109).

Melucci A (1989) Nomads of the Present. Londres: Temple University Press.

Melucci A (1999). Acción Colectiva, Vida Cotidiana y Democracia. México: El Colegio de México.

Naredo J M (1998) La Burbuja Inmobiliariofinanciera en la Coyuntura Económica reciente. Madrid: Siglo XXI.

Naredo J M, Carpintero O and Marcos C (2008) Patrimonio Inmobiliario y Balance Nacional de la
Economía Española (1995-2007). Madrid: Fundación de las Cajas de Ahorro Confederadas.

Pastor J (2006) "Los movimientos sociales. De la crítica de la modernidad a la denuncia de la globalización”, en Intervención Psicosocial, Vol. 15 N. 2 Págs. 133-147.

Preston P (2011) El Holocausto Español. Debate: Barcelona.

Prujit H (2003) Is the Institutionalization of Urban Movements Inevitable? A Comparison of the Opportunities for Sustained Squatting in New York City and Amsterdam. International Journal of Urban and Regional Research 1(27): 133-157.

Rodríguez-López E and López-Hernández I (2011) Del Auge al Colapso. El Modelo Financiero-inmobiliario de la Economía Española (1995-2010). Revista de Economía Crítica 12.

Sargatal M A (2003) La Vivienda en el Centro Histórico de Barcelona. El caso de la Rambla del Raval. Scripta Nova 146(7).

Tezanos J F (1984) Cambio Social y Modernización en la Espańa Actual. REIS 28: 19-61.

Tezanos J F (2002) Desigualdad y Exclusión Social en las Sociedades Tecnológicas. Revista del Ministerio de Trabajo y asuntos sociales 35: 35-53.

Tomé S (2007) Los Centros Históricos de las Ciudades Españolas. Ería 72: 75-88.

Torres F J (2013) Segregación urbana y exclusión social en Sevilla. El paradigma de Polígono Sur. Sevilla: Universidad de Sevilla y Fundación Focus-Abengoa.

Touraine A (1973) La imagen histórica de la sociedad de clases. Buenos Aires: Nueva Visión.

VVAA (2007) Madrid ¿La Suma de Todos? Globalización, Territorio, Desigualdad. Madrid: Traficantes de Sueños. 